\title{
Inflammatory and Ischemic Post Liver Transplant Complications Mimic Malignancy on 18 F-FDG PET/CT
}

\author{
Enflamatuvar ve Iskemik Karaciğer Transplantasyonu Komplikasyonları I8F-FDG PET/BT'de \\ Maligniteyi Taklit Eder
}

(1) William Makis I, (1) Anthony Ciarallo2, (1) Stephan Probst3

' Cross Cancer Institute, Department of Diagnostic Imaging, Edmonton, Canada

2McGill University Health Centre, Department of Nuclear Medicine, Montreal, Canada

3)ewish General Hospital, Department of Nuclear Medicine, Montreal, Canada

\begin{abstract}
A 65-year-old male patient with a one year history of liver transplantation was referred for an 18F-fluoro-2-deoxy-D-glucose (18F-FDG) positron emission tomography/computed tomography (PET/CT) to rule out post transplant lymphoproliferative disease. Multiple foci of intense abnormal 18F-FDG uptake were seen in the transplanted liver which were concerning for malignancy. Explantation of the liver approximately 1 month following the PET/CT revealed multiple inflammatory and ischemic changes including large bile duct necrosis, acute cholangitis, bile duct obstruction changes and periportal fibrosis, with no evidence of malignancy. We present the 18F-FDG PET/CT image findings of this case.

Keywords: Liver transplant, complications, pitfall, artifact, 18F-fluorodeoxyglucose, positron emission tomography
\end{abstract}

\section{Öz}

Altmış beş yaşında bir erkek hasta karaciğer transplantasyonundan bir yıl sonra post transplant lenfoproliferatif hastalık açısından değerlendirilmek üzere 18F-fluoro-2-deoxy-D-glucose (18F-FDG) pozitron emisyon tomografisi/bilgisayarlı tomografi (PET/BT) için yönlendirildi. Transplante karaciğerde malignite şüphesi uyandıran multipl yoğun 18F-FDG tutulumu saptandı. $\mathrm{PET} / \mathrm{BT}^{\prime}$ den 1 ay sonra yapılan karaciğer eksplantasyonunda multipl enflamatuvar ve iskemik değişiklikler, safra kanalı nekrozu, akut kolanjit, safra yolu obstrüksiyonuna bağlı değişiklikler ve periportal fibrozis saptandı, malignite bulgusu görülmedi. Bu olgunun 18F-FDG PET/BT görüntüleme bulgularını sunuyoruz.

Anahtar kelimeler: Karaciğer transplantasyonu, komplikasyon, tuzak, artefakt, 18F-fluorodeoxyglucose, pozitron emisyon tomografisi

Address for Correspondence: William Makis MD, Cross Cancer Institute, Department of Diagnostic Imaging, Edmonton, Canada Phone: +90 7804328760 E-mail: makisw79@yahoo.com ORCID ID: orcid.org/0000-0003-0241-3426

Received: 31.12.2016 Accepted: 15.10.2017

${ }^{\circ}$ Copyright 2018 by Turkish Society of Nuclear Medicine

Molecular Imaging and Radionuclide Therapy published by Galenos Yayınevi. 


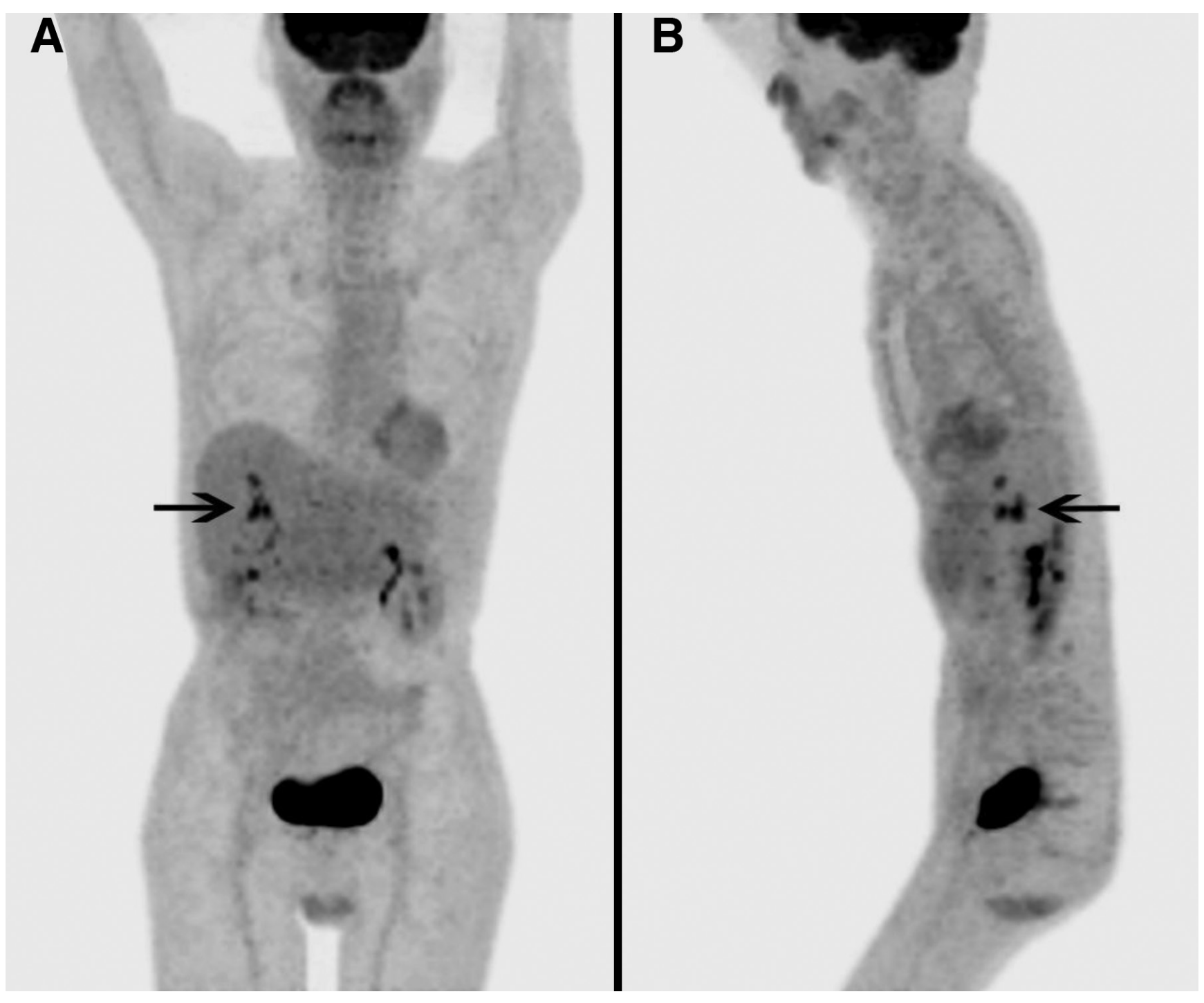

Figure 1. A 65-year-old male had a liver transplant one year prior, for hepatitis B cirrhosis and hepatocellular carcinoma (HCC) with a $3.5 \mathrm{~cm}$ lesion in the left lobe and a $4 \mathrm{~cm}$ lesion in the right. For several months prior to positron emission tomography/computed tomography (PET/CT), the patient had persistently elevated liver function tests but multiple transjugular biopsies showed no evidence of transplant rejection. Seven endoscopic retrograde cholangiopancreatographies (ERCPs) were performed as the patient developed recurring stenoses and strictures of intrahepatic bile ducts, with failed attempts of cannulation, balloon dilation and stent replacements. The patient tested positive for Epstein-Barr virus and underwent PET/CT to rule out post transplant lymphoproliferative disease (PTLD). Maximum intensity projection images showed multiple foci of intense ${ }^{18 F-F D G ~ u p t a k e ~ i n ~ t h e ~ l i v e r ~}$ in segments 5, 6, 7 and 8, with maximum standardized uptake value of 9.0, concerning for malignancy. 

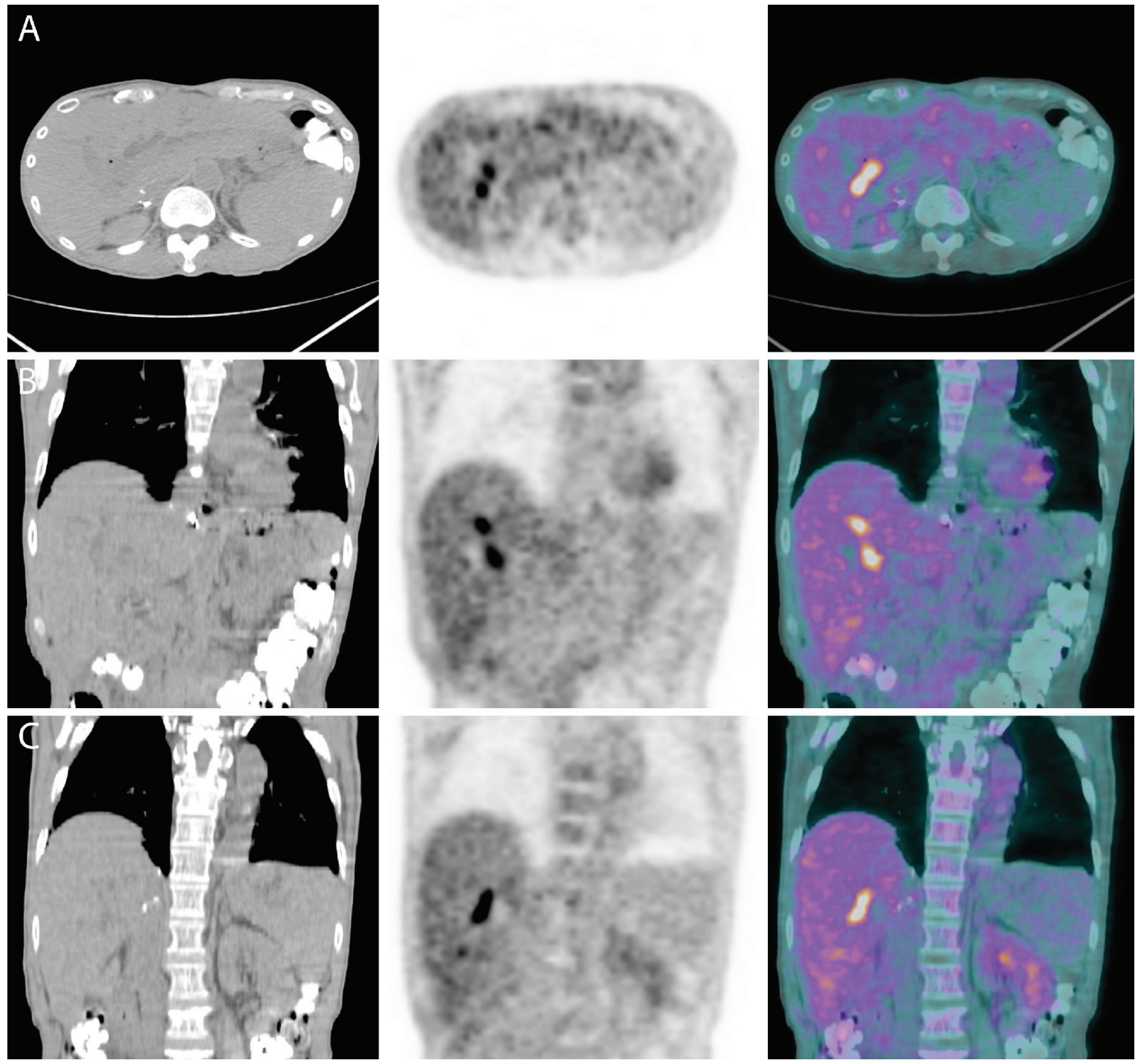

Figure 2. Transaxial and coronal views of the PET/CT fusion images showed multiple foci of intense 18 F-FDG uptake in the liver, although no obvious mass lesions were seen on the CT. An ERCP done 1 month after PET/CT showed multiple strictures involving the common hepatic duct and its intrahepatic segments associated with stones, debris and a failed right hepatic biliary stent. The liver was explanted and histopathological evaluation showed a cirrhotic liver weighing $1260 \mathrm{~g}$ measuring $20 \times 14.5 \times 7.2 \mathrm{~cm}$. The surface of the liver revealed homogeneous macronodular appearance with absence of infarctions. Ducts of the right and left lobe appeared dilated, and sectioning showed large bile duct necrosis, acute cholangitis, bile duct obstruction changes and periportal fibrosis (stage 2/4). There was no evidence of malignancy within the explanted liver. Liver transplantation is a standard treatment for patients with end stage liver disease. Biliary complications of liver transplantation remain a significant problem with bile leak and stricture rates of $\sim 20 \%$, majority of them being related to biliary anastomosis $(1,2)$. Re-transplantation is required following the development of ischemic type biliary strictures or ischemic cholangiopathy which is defined as intra or extra-hepatic biliary stricture in the presence of a patent hepatic artery (3). The only ${ }^{18 F-F D G ~ p o s i t i v e ~ l i v e r ~ t r a n s p l a n t ~ c o m p l i c a t i o n s ~ r e p o r t e d ~ i n ~ t h e ~ l i t e r a t u r e ~ a r e ~ P T L D ~ a n d ~ r e c u r r e n t ~ H C C ~(4,5) . ~}{ }^{18 F-F D G ~ P E T / C T ~ i s ~ w i d e l y ~}$ used to assess for extrahepatic metastases prior to liver transplantation (6). PET/CT has also been found to be useful as a predictive parameter for evaluation of early HCC recurrence after liver transplantation (7). In light of the increasing use of PET/CT in liver transplant patients, it is important to be aware of lesions that mimick malignancy. In our case, foci of increased 18F-FDG uptake in the transplanted liver were concerning for malignancy but were found to be benign inflammatory and ischemic changes including large bile duct necrosis, acute cholangitis, bile duct obstruction changes and periportal fibrosis. In non-transplanted liver, several non-malignant processes have been described to take up 18F-FDG including: intrahepatic cholestasis (8), acute cholangitis $(9,10)$, sclerosing cholangitis (11), liver abscess $(12,13)$, hepatic pseudotumor (14), and hepatic sarcoidosis (15). 


\section{Ethics}

Informed Consent: All subjects in the study gave written informed consent or the institutional review board waived the need to obtain informed consent.

Peer-review: Externally peer-reviewed.

\section{Authorship Contributions}

Surgical and Medical Practices: W.M., A.C., S.P., Concept: W.M., Design: W.M., Data Collection or Processing: W.M., A.C., S.P., Analysis or Interpretation: W.M., A.C., S.P., Literature Search: W.M., A.C., S.P., Writing: W.M.

Conflict of Interest: No conflict of interest was declared by the authors.

Financial Disclosure: The authors declared that this study received no financial support.

\section{References}

1. Patkowski W, Nyckowski P, Zieniewicz K, Pawlak J, Michalowicz B, Kotulski M, Smoter P, Grodzicki M, Skwarek A, Ziolkowski J, Oldakowska-Jedynak U, Niewczas M, Paczek L, Krawczyk M. Biliary tract complications following liver transplantation. Transplant Proc 2003;35:2316-2317.

2. Welling TH, Heidt DG, Englesbe MJ, Magee JC, Sung RS, Campbell DA, Punch JD, Pelletier SJ. Biliary complications following liver transplantation in the model for end-stage liver disease era: effect of donor, recipient, and technical factors. Liver Transpl 2008;14:7380.

3. Foley DP, Fernandez LA, Leverson G, Anderson M, Mezrich J, Sollinger HW, D'Alessandro A. Biliary complications after liver transplantation from donation after cardiac death donors: an analysis of risk factors and long term outcomes from a single center. Ann Surg 2011;253:817-825
4. McCormack L, Hany TI, Hubner M, Petrowsky H, Mullhaupt $B$, Knuth A, Stenner F, Clavien PA. How useful is PET/CT imaging in the management of post-transplant lymphoproliferative disease after liver transplantation? Am J Transplant 2006;6:1731-1736.

5. Takehana CS, Twist CJ, Mosci C, Quon A, Mittra E, lagaru A. 18F-FDG PET/CT in the management of patients with post-transplant lymphoproliferative disorder. Nuc Med Comm 2014;35:276-281.

6. Mocherla B, Kim J, Roayaie S, Kim S, Machac C, Kostakoglu L. FDG $\mathrm{PET} / \mathrm{CT}$ imaging to rule out extrahepatic metastases before liver transplantation. Clin Nucl Med 2007;32:947-948.

7. Lee SD, Kim SH, Kim YK, Kim C, Kim SK, Han SS, Park SJ. 18F-FDG PET/ CT predicts early tumor recurrence in living donor liver transplantation for hepatocellular carcinoma. Transplant Int 2013;26:50-60.

8. Frohlich A, Diederichs CG, Staib L, Vogel J, Beger HG, Reske SN. Detection of liver metastases from pancreatic cancer using FDG PET. J Nucl Med 1999:40:250-255.

9. Bleeker-Rovers CP, Vos FJ, Wanten GJ, van der Meer JW, Corstens FH, Kullberg BJ, Oyen WJ. 18F-FDG PET in detecting metastatic infectious disease. J Nucl Med 2005;46:2014-2019.

10. Kitajima K, Murakami K, Yamasaki E, Domeki Y, Kaji Y, Morita S, Suganuma N, Sugimura K. Performance of integrated FDG-PET/ contrast-enhanced $\mathrm{CT}$ in the diagnosis of recurrent uterine cancer: comparison with PET and enhanced CT. Eur J Nucl Med Mol Imaging 2009;36:362-372.

11. Kawamura E, Habu D, Higashiyama $S$, Tsushima $H$, Shimonishi $Y$ Nakayama Y, Enomoto M, Kawabe J, Tamori A, Kawada N, Shiomi S. A case of sclerosing cholangitis with autoimmune pancreatitis evaluated by FDG-PET. Ann Nucl Med 2007;21:223-228.

12. Keidar Z, Gurman-Balbir A, Gaitini D, Israel O. Fever of unknown origin: the role of 18F-FDG PET/CT. J Nucl Med 2008;49:1980-1985.

13. Delbeke D, Martin WH, Sandler MP, Chapman WC, Wright JK Jr, Pinson CW. Evaluation of benign vs malignant hepatic lesions with positron emission tomography. Arch Surg 1998;133:510-516.

14. Kawamura E, Habu D, Tsushima H, Torii K, Kawabe J, Ohsawa M, Shiomi S. A case of hepatic inflammatory pseudotumor identified by FDG-PET. Ann Nucl Med 2006;20:321-323.

15. Guglielmi AN, Kim BY, Bybel B, Slifkin N. False-positive uptake of FDG in hepatic sarcoidosis. Clin Nucl Med 2006;31:175. 